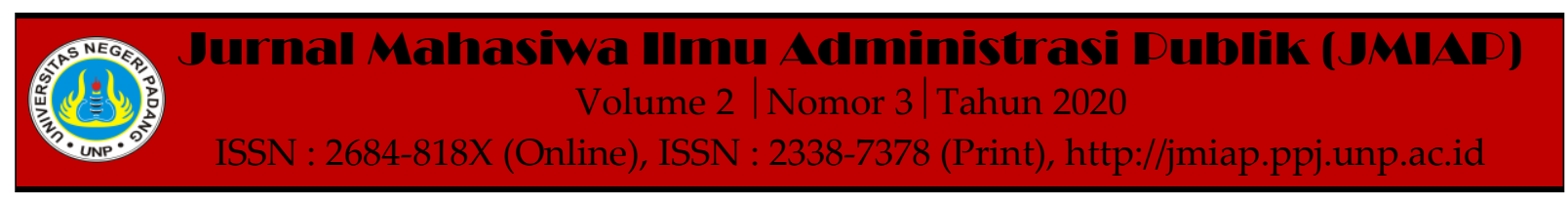

\title{
PELAKSANAAN KODE ETIK APARATUR SIPIL NEGARA DI KANTOR BKPSDM KABUPATEN TANAH DATAR
}

\author{
Ranti Hanafiah $^{1(a)}$, Karjuni Dt. Maani2(b) \\ ${ }^{1}$ Jurusan Ilmu Administrasi Negara, Universitas Negeri Padang \\ ${ }^{2}$ Jurusan Ilmu Administrasi Negara, Universitas Negeri Padang \\ a) rantyhanafyah1997@gmail.com, ${ }^{b)}$ karjuni.dtmaani@fis.unp.ac.id
}

\begin{abstract}
The Code of Ethics is a rule that contains behavior that must be obeyed by those who carry out certain professional duties. However, until now there are still found violations of the code of ethics discipline in Tanah Datar District. This study aims to describe the implementation of the Code of Ethics for State Civil Servants at the Office of the Civil Service and Human Resources Development of Tanah Datar Regency, as well as to identify obstacles in the implementation of the Code of Ethics for State Civil Servants at the Office of the Civil Service Agency and Human Resources Development of Tanah Data Regency. This research uses qualitative research using descriptive method which is done by purposive sampling. Data collection techniques were carried out by observation, interviews and documentation study, with sources from several employees at the Office of the Civil Service and Human Resources Development of Tanah Datar Regency and several communities related to the Implementation of the Code of Ethics for State Civil Servants. One of the actions of the Tanah Datar District Civil Service and Human Resources Development Agency against State Civil Servants who commit disciplinary violations is by giving warnings and reductions in accordance with Government Regulation Number 53 of 2010 concerning Civil Servant Discipline.
\end{abstract}

Keywords : Code of Ethics, ASN, BKPSDM, Tanah Datar

Corresponding author. Email. rantyhanafyah1997@gmail.com

How to cite this article. Hanafiah, R \& Ma'ani, K. Dt (2020). Pelaksanaan Kode Etik Aparatur Sipil Negara di Kantor BKPSDM Kabupaten Tanah Datar. Jurnal Mahasiwa Ilmu Administrasi Publik (JMIAP) Jurusan Ilmu Administrasi Negara Fakultas Ilmu Sosial Universitas Negeri Padang, Volume 2 (3), Hal. 125-133.

http://jmiap.ppj.unp.ac.id

ISSN : 2684-818X (Online), ISSN : 2338-7378 (Print)

Copyright@2020. Published by Labor Jurusan Ilmu Administrasi Negara FIS UNP, Padang 


\section{PENDAHULUAN}

Aparatur Sipil Negara atau yang disingkat menjadi ASN merupakan profesi bagi pegawai negeri sipil dan juga pegawai pemerintahan dengan adanya perjanjian kerja yang bekerja pada instansi pemerintah. Pegawai Negeri Sipil (PNS) merupakan warga negara Indonesia yang memenuhi syarat tertentu dalam rangka melaksanakan tugas pemerintah.

Berdasarkan UU Nomor 5 Tahun 2014 pada Bab IV Pasal 12 menjelaskan bahwa Pegawai ASN berperan sebagai perencanaan, pelaksanaan, dan pengawasan penyelenggaraan tugas umum pemerintahan dan pembangunan nasional melalui pelaksanaan kebijakan dan pelayanan publik yang profesional, bebas dari intervensi politik, serta bersih dari praktik korupsi, kolusi, dan nepotisme.

Menurut Kusmanadji (2004:1) Kode Etik berisi aturan perilaku yang harus dipatuhi oleh setiap mereka yang menjaankan tugas profesi tertentu. Kode Etik Aparatur Sipi Negara memiliki tujuan antara lain yaitu agar ASN dapat memberikan pelayanan dengan sebaik baiknya kepada orang yang dilayani sesuai dengan aturan yang ada. Sesuai dengan aturan yang teah ditetapkan oleh pemerintah Aparatur Sipil Negara memiliki tanggungjawab setiap tugas dan kedudukannya yang di milikinya. Dalam melaksanakan tugasnya ASN harus bersikap disiplin dan cermat. Sikap disiplin merupakan suatu tindakan sikap dan norma yang harus diterapkan oleh ASN.

Kode Etik adalah pedoman mengenai kewajiban moral Aparatur Sipil Negara yang harus ditunjukkan dalam melaksanakan tugas dan pergaulan hidup sehari-hari. Kode Perilaku adaah pedoman mengenai sikap, tingkah laku, perbuatan, tulisan, dan ucapan ASN dalam melaksanakan tugasnya dan pergaulan hidup sehari-hari yang merujuk pada kode etik

Dalam melaksanakan tugasnya Aparatur Sipil Negara bisa menjaga kerahasiaan yang menyangkut kebijakan Negara, menjaga agar tidak terjadi konflik kepentingan dalam melaksanakan tugasnya. Masih ada Aparatur Sipi Negara yang disaat melaksanakan tugasnya terjadi konflik kepentingan. Hal tersebut banyaknya Aparatur Sipil Negara yang mementingkan kepentingan pribadi dimana menyalahgunakan informasi intern Negara, tugas, status, kekuasaan, untuk mendapatkan atau mencari keuntungan atau menfaat bagi diri sendiri atau untuk orang lain.

Badan Kepegawaian dan Pengembangan Sumberdaya Manusia (BKPSDM) Kabupaten Tanah Datar adalah salah satu organisasi pemerintah Kabupaten dalam pelayanan ASN. Dimana Visi BKPSDM Kabupaten Tanah Datar 20162021 adalah terwujudnya Aparatur Sipil Negara yang berintegritas dan profesional. Sedangkan Misi BKPSDM Kabupaten Tanah Datar 20162021 adalah : (1) Mewujudkan Aparatur yang berkualitas, (2) Mewujudkan pengelolaan manajemen ASN yang profesional dan akuntabel.

\section{TINJAUAN PUSTAKA}

Implementasi Merupakan tahap realisasi tujuan-tujuan program. Dalam hal ini yang perlu diperhatikan ialah persiapan implementasi, yaitu memikirkan dan menghitung secara matang berbagai kemungkinan keberhasilan dan kegagalan termasuk hambatan atau peluang-peluang yang ada dan kemampuan organisasi yang diserahi tugas melaksanakan program (Mulyadi, 2016:25).

Implementasi merupakan langkah yang sangat penting dalam proses kebijakan. Banyak kebijakan yang baik yang mampu dibuat oleh pemerintah, tetapi kemudian ternyata tidak mempunyai pengaruh apaapa dalm kehidupan negara tersebut karena tidak dilaksanakan. Implementasi kebijakan merupakan tahap yang terpenting pada kebijakan. Pada tahap ini menentukan apakah kebijakan yang ditempuh oleh pemerintah benar-benar aplikabel atau diterima di lapangan dan berhasil untuk menghasilkan output dan outcomes seperti 
yang telah direncanakan. Output merupakan keluaran kebijakan yang diharapkan dapat muncul sebagai keluaran langsung dari kebijakan. Output biasanya dapat dilihat dalam waktu yang singkat pasca atau setelah implementasi kebijakan. Outcomes yaitu akibat dari kebijakan, yang diharapkan dapat timbul setelah keluarnya output kebijakan. Outcomes biasanya diukur setelah keluarnya output atau dalam waktu yang lama pasca implementasi kebijakan (Dwiyanto, 2009:143).

Model Implementasi kebijakan oleh Meter dan Horn yaitu menetapkan beberapa variabel yang diakui dapat mempengaruhi implementasi dan kinerja kebijakan. Adapun variabel yang ada dalam model Meter dan Horn adalah sebagai berikut (Indiahono, 2009:38) ; (1) Standar dan sasaran kebijakan Adalah apa yang akan dicapai oleh program ataupun kebijakan, baik yang berwujud ataupun tidak, jangka pendek, menengah ataupun panjang. Harus adanya kejelasan dan sasaran kebijakan secara spesifik agar di akhir program dapat dilihat keberhasilan atau kegagalan dari kebijakan ataupun program yang dijalankan; (2) Kinerja kebijakan Adalah penilaian terhadap pencapaian standar ataupun sasaran kebijakan yang telah ditetapkan di awal; (3) Sumber daya, Dimana merujuk pada seberapa besar dukungan finansial dan juga sumber daya manusia untuk menjalankan program atau kebijakan; (4) Komunikasi antar badan pelaksana Yaitu kepada mekanisme prosedur yang telah dicanangkan untuk mewujudkan sasaran dan tujuan program. Komunikasi diantara organisasi juga merujuk adanya tuntutan saling dukung antar institusi yang berkaitan dengan program/kebijakan; (5) Karakteristik badan pelaksana Merupakan seberapa besar daya dukung dari struktur organisasi, nilai-nilai yang berkembang, hubungan dan juga komunikasi yang ada di internal birokrasi; (6) Lingkungan sosial, ekonomi dan politik, bahwa lingkungan terhadap ranah implementasi dapat mempengaruhi keberhasilan implementasi kebijakan itu sendiri; ()Sikap pelaksana adalah sikap pelaksanaan menjadi variabel yang penting dalam implementasi klebijakan. Dimana seberapa demokratis, antusias dan responsif dalam kelompok sasaran dan juga lingkungan yang dapat ditunjuk sebagai bagian terhadap sikap pelaksanaan.

Menurut Hogwood dan Gunn dalam Solichin (2014:71) agar dapat melaksanakan kebijakan secara baik maka diperlukan beberapa persyaratan tertentu yaitu ; (1) Kondisi eksternal yang dihadapi oleh badan/instsnsi pelaksana tidak akan menimbulkan gangguan/kendala yang serius; (2) Untuk pelaksanaan program tersedia waktu dan sumber-sumber yang cukup memadai; (3) Perpaduan sumbersumber yang diperlukan benar-benar tersedia; (4) Kebijakan yang akan diimplementasikan didasari oleh suatu hubungan kausalitas yang andal; (5) Hubungan kausalitas bersifat langsung dan hanya sedikit mata rantai penghubungannya; (6) Hubungan saling ketergantungan harus kecil; ()Pemahaman yang mendalam dan kesepakatan terhadap tujuan; (8) Tugas-tugas diperinci dan ditetapkan dalam urutan yang tepat; (9) Komunikasi dan koordinasi yang sempurna; dan (10) Pihak-pihak yang memiliki wewenang kekuasaan dapat menuntut dan mendapatkan kepatuhan yang sempurna.

Menurut Gow dan Morss (dalam Harbani, 2010:59) implementasi kebijakan mempunyai beberapa faktor pemhambat antara lain : (1) Hambatan politik, ekonomi, dan lingkungan; (2) Kelemahan intitusi; (3) Ketidak mampuan sumber daya manusia di bidang teknis dan administratif; (4) Kekurangan dalam bentik teknis; (5) Kurangnya desentralisasi dan partisipasi; (6) Pengaturan waktu (timing); () Sistem informasi yang kurang mendukung; (8) Perbedaan agenda tujuan antara aktor; dan (9) Dukungan yang berkesinambungan.

Konsep Kode etik berisi aturan perilaku yang harus dipatuhi oleh setiap mereka yang menjalankan tugas profesi tertentu. Definisi lain dari Kusmanadji (2004 : 1) mengatakan bahwa etika adalah sebuah 
refleksi kritis dan rasional mengenai : 1) Nilai dan norma yang menyangkut bagaimana manusia, sebagai manusia, harus hidup baik, dan 2) Masalah-masalah kehidupan manusia dengan mendasarkan diri pada nilai dan norma-norma moral yang umum diterima.

Dalam Peraturan Menteri Dalam Negeri Nomor 28 Tahun 2007 tanggal 30 Mei 2007 tentang Norma Pengawasan dan Kode Etik Pejabat Pengawas Pemerintah dalam ketentuan pasal 1 point 2 menyebutkan Kode Etik Pejabat Pengawas Pemerintah adalah seperangkat prinsip moral atau nilai yang dipergunakan oleh pejabat pengawas pemerintah sebagai pedoman tingkah laku dalam melaksanakan tugas pengawasan. Kode Etik merupakan sistem prinsip moral yang diberlakukan dalam suatu kelompok profesi yang diterapkan dan wajib ditaati oleh para anggotanya.

Konsep Aparatur Sipil Negara (ASN) saat ini belum begitu dikenal masyarakat indonesia dibandingkan dengan istilah PNS yang sudah dikenal sejak dahulu. Bahkan PNS sendiri pun masih banyak yamg tidak mengetahui esensi dari ASN itu sendiri. Hal tersebut dikarenakan sosialisasi ASN tidak begitu gencar oleh pemerintahan sejak tahun 2014 dimana pada tanggal 15 Januari, Presiden RI, Susilo Bambang Yudhoyono, saat itu telah menandatangani UndangUndang Aparatur Sipil Negara (UU ASN) yang telah disetujui oleh rapat Paripurna menjadi Undang-Undang Nomor 5 Tahun 2014.

Kode Etik Pejabat Pengawas Pemerintah adalah seperangkat prinsip moral atau nilai yang dipergunakan oleh pejabat pengawas pemerintah sebagai pedoman tingkah laku dalam melaksanakan tugas pengawasan. Kode Etik merupakan sistem prinsip moral yang diberlakukan dalam suatu kelompok profesi yang diterapkan dan wajib ditaati oleh para anggotanya.

Unsur etika sangat menyatu dalam sebuah norma hukum, jika kedua unsur ini dilanggar, tentu sanksi akan ditegakkannya, seperti halnya seseorang dalam kehidupannya selalu melanggar etika dan merugikan perorangan atau kelompok tertentu, maka perlu dijatuhi sanksi yang seimbang dengan perbuatannya. Indonesia, secara socio-historis merupakan lembaga perwakilan rakyat yang baru mempunyai Badan Kehormatan dalam menerapkan kode etik.

Menurut Anggara (2016: 402), menyatakan bahwa etika birokrasi adalah norma atau nilai-nilai moral yang menjadi pedoman bagi keseluruhan aparat pemerintah dalam menjalankan tugas dan kewajibannya demi kepentingan umum atau masyarakat, dengan demikian aparat pemerintah seharusnya mempunyai pedomandan penuntun dalam sikap dan perilaku sehingga birokrasi menjadi bersih, dinamis dan bertanggungjawab.

Pegawai Negeri Sipil, Menurut Kamus Umum Bhasa Indonesia, "Pegawai"berarti" orang yang bekerja pada pemerintah (perusahaan dan sebagainya). Sedangkan "Negeri" berarti negara atau pemerintah, jadi pegawai negeri sipil adalah orang yang bekerja pada pemerintah atau negara.

Subtansi yang terkandung dalam Undang-Undang ASN di antaranya menegaskan bagwa ASN adalah sebuah bentuk profesi bagi PNS dan PPPK (Pegawai Pemerintah dengan Perjanjian Kerja), dengan penetapan ASN sebagai sebuah profesi, maka diperlukan adanya, nilai dasar, kode etik dan kode perilaku, serta pengembangan kompetensi.

Berdasarkan Peraturan UU Nomor 5 Tahun 2014 Tentang Aparatur Sipil Negara di Kantor Badan Kepegawaian dan Sumber Daya Manusia di Kabupaten Tanah Datar dalam pasal 1 ayat 1 dijelaskan bahwa : Aparatur Sipil Negara yang disingkat menjadi ASN adalah profesi bagi pegawai negeri sipil dan pegawai pemerintah dengan perjanjian kerja yang bekerja pada instansi pemerintah. Berdasarkann Pasal 5 Ayat 2 di jelaskan bahwa Kode etik dan Kode Perilaku ASN yaitu : 1) Melaksanakan tugasnya dengan jujur, bertanggungjawab, dan berintegritas tinggi; 2) Melaksanakan dengan sikap hormat,sopan,dan tanpa tekanan; 3) Melaksanakan tugasnya sesuai 
dengan ketentuan peraturan perundang undangan; 4) Melaksanakan tugasnya sesuai dengan perintah atasan pejabat baru yang berwewenang sejauh tidak bertentangan dengan ketentuan peraturan perundang undangan; 5) Menjaga kerahasiaan yang menyangkut kebijakan Negara; 6) Menggunakan kekayaan dan barang milik Negara secara bertanggungjawab, efektif, dan efisien; ) Menjaga agar tidak terjadi konflik kepentingan dalam melaksanakan tugasnya; 8) Memberi informasi secara benar dan tidak menyesatkan kepada pihak lain yang memerlukan informasi terkait kepentingan kedinasan; 9) Tidak menyalahgunakan informasi intern Negara, tugas, status, kekuasaan, dan jabatan untuk mendapat atau mencari keuntungan atau manfaat bagi diri sendiri atau untuk orang lain; 10) Memegang teguh nilai dasar ASN dan selalu menjaga reputasi dan integritas ASN; dan 11) Melaksanakan ketentuan peraturan perundang undangan mengenai disiplin Pegawai ASN.

\section{METODE PENELITIAN}

Penelitian ini adalah kualitatif dengan metode deskriptif. Lokasi penelitiannya adalah di Kantor Badan Kepegawaian Dan Pengembangan Sumberdaya Manusia Kabupen Tanah Datar. Dengan menggunakan informan penelitian melalui teknik Purposive Sampling adalah memilih informan yang dapat mengetahui informasi sesuai masalah dalam penelitian. Adapun informan penelitiannya adalah Kepala Sub Bagian Umum Dan Kepegawaian, Kepala Sub Bidang Pembinaan, Kepala Bidang Pengembangan Kompetensi Dan Pembinaan, Kepala Sub Bidang Organisasi Profesi Aparatur Sipil Negara dan stakeholder terkait lainnya, serta teknik pengumpulan data dilakukan dengan cara wawancara dan studi dokumentasi.

\section{HASIL DAN PEMBAHASAN}

Pelaksanaan Kode etik Aparatur Sipil Negara di Kantor Badan Kepegawaian dan Pengembangan Sumber Daya Manusia
Kabupaten Tanah Datar sesuai dengan Undang undang Nomor 5 Tahun 2014 Tentang Aparatur Sipi Negara Pasa 5 Ayat 1 yaitu ; (1) Melaksanakan tugasnya dengan jujur, bertanggungjawab, dan berintegritas tinggi.

Melaksanakan tugas dengan jujur, bertanggungjawab, dan berintegritas tinggi merupakan hal yang harus dimiliki oleh Aparatur Sipil Negara. Pemerintah mengeluarkan kebijakan tentang Kode Etik ini pada dasarnya adalah untuk menciptakan Aparatur Sipil Negara yang sesuai dengan Aturan yang telah ditetapkan, agar Aparatur Sipil Negara memberikan layanan yang maksimal kepada masyarakat. Hal tersebut tentunya akan ada pelanggaran ataupun penyimpangan terhadap pelaksanaan kode etik Aparatur Sipil Negara tersebut. Baik itu pelanggaran kecil ataupun pelanggaran besar. Dalam rangka mengantisipasi segara permasalahan mengenai gangguan akibat pelaksanaan kode etik Aparatur Sipil Negara tersebut maka pemerintah daerah telah menetapkan aturan hukum yang mengatur tentang Aparatur Sipil Negara Tersebut.

Sementara dalam hasil temuan penulis komunikasi yang dilakukan dalam penerapan ASN yang jujur, bertanggungjawab, dan berintegritas tinggi sudah diterapkan. Hanya saja masih ada pelanggaran yang terjadi, salah satu faktornya adalah kesadaran dari ASN tersebut. Yang mana dalam melaksanakan pekerjaan nantiknya akan ada pelanggaran yang dilakukan ataupun tidak sesuai aturan yang ditetapkan.

Adapun tujuan dari Pelaksanaan Kode Etik Aparatur Sipil Negara ini adalah agar ada patokan dan pedoman Aparatir Sipil Negara Khusus nya di Kantor Bdan Kepegawaian Dan Pengembangan Sumberdaya Manusia dalam bersikap dan bertindaka dalam jam kerja ataupun memberikan layanan kepada masyarakat. Sesuai dengan yang ditetapakan UndangUndang Republik Indonesia Nomor 5 tahun 2014 Tentang Aparatur Sipil Negara pada Pasal 5 dijelaskan point-point bagaimana 
kode etik dan kode perilaku Aparatur Sipil Negara; (2) Melaksanakan tugasnya dengan cermat dan disiplin didalam melaksanakan tugas Aparatur Sipil Negara tentunya harus cermat dan disiplin. Hal tersebut merupakan suatu yang hari dimiliki Aparatur Sipil negara. Disiplin merupakan perasaan taat dan patuh terhadap nilai-nilai yang dipercaya merupakan tanggung jawabnya. Hal tersebut tentunya memiliki sumberdya yang baik, karena memiliki sumberdaya yang baik tentunya pekerjaan yang diberikan akan dijalankan sesuai dengan aturan aturan yang telah ditetapkan.

Sumber daya merukan hal yang sangat mempengaruhi keberhasilan dalam proses implementasi ataupun pelaksanaan, baik itu sumberdaya financial maupun sumber daya manusia. Tanpa adanya sumberdaya maka tahap implementasi atau pelaksanaan tidak akan berjalan dengan baik, karena hal tersebut perlu didukung oleh sumberdaya yang memadai dalam hal ini sumberdaya manusia. Sumberdaya manusia sangan penting karena sebagian sumberdaya penggerak dan pelaksana, Pelaksanaan Kode Etik Aparatur Sipil Negara ini tentu saja membutuhkan sumberdaya manusia yang mempunyai kualitas maupun kuantitas, serta bertanggung jawab dalam melaksanakan tugas dibidang masingmasing.

Sementara dalam hasil temuan penulis yang dilakukan dari hasil wawancara bahwa untuk untuk melaksanakan tugasnya dengan cermat dan disiplin Kantor Badan Kepegawaian dan Pengembangan Sumberdaya Manusia Kabupaten Tanah Datar sudah memiliki staff yang cukup hanya dalam pelaksanaan kerja kurang memberikan layanan yang baik. Selain itu juga kurang disiplin, dimana masih ada yang terlambat dan tidak masuk kerja tanpa keterangan; (3) Melayani dengan sikap hormat, sopan, dan tanpa tekanan.

Sikap hormat adalah sikap yang menghargai orang lain. Tidak hanya kepada orang yang dilayani, tetapi sesama pegawai Aparatur Sipil Negara tentunya harus saling menghormati, sopan. Selain itu di dalam melaksanakan tugas, tidak boleh adanya tekanan.

Sikap sopan di dalam pekerjaan merupakan suatu tindakan yang menghargai, beretika baik dan memiliki norma yang baik. Salah satunya sopan dalam berbicara sesama Aparatur Sipil Negara. Saling berkomunikasi dengan baik akan menimbulkan keakraban sesama Aparatur Sipil Negara.

Sementara dalam hasil temuan penulis komunikasi yang dilakukan antar badan pelaksana bisa dikatakan sudah berjalan dengan baik namun komunikasi yang dilakukan antar masyarakat kuang baik. Hal tersebut masih belum relevan dengan teori yang dikemukakan oleh Van Meter dan Van Horn (dalam Nawawi, 2009:140) komunikasi badan pelaksana, menunjuk kepada mekanisme prosedur yang dicanangkan untuk mencapai sasaran dan tujuan program; (4) Melaksanakan tugasnya sesuai dengan ketentuan peraturan perundang undangan. Peraturan merupakan suatu kegiatan yang harus dilaksanakan oleg ASN sesuai dengan aturan yang telah ditetapkan. Hal tersebut bertujuan agar melaksanakan tugas dengan baik dan efektif sesuai dengan tujuan yang telah ditetapkan.

Sikap para pelaksana dalam menjalankan tugas dan tanggungjawab sebagai pelaksana kebijakan seberapa demokratis, antusias dan responsif terhadap kelompok sasaran dan lingkungan beberapa yang dapat ditunjuk sebagai bagian dari sikap pelaksana ini. Hal tersebut dilakukan karena dapat mempengaruhi keberhasilan pelaksanaan Kode Etik ASN. Setiap badan/instansi Pelaksanaan Kode Etik ASN harus melaksanakan tugas sesuai aturan yang ada; (5) Menggunakan kekayaan dan barang milik negara secara bertanggungjawab, efektif, dan efisien.

Barang Milik Negara adalah semua barang yang dibeli atau diperoleh atas beban Anggaran. Untuk menunjang pekerjaan Aparatur Sipil Negara pemerintah memfasilitasi ASN. Seperti dengan memberikan komputer, alat alat tulis dan perlengkapan lainnya. Pada Kantor 
Badan Kepegawaian dan Pengembangan Sumberdaya Manusia Kabupaten Tanah Datar masih ditemukan barang barang yang rusak dan hilang.

\section{Gambar 1. Data Barang Milik Negara yang Hilang}

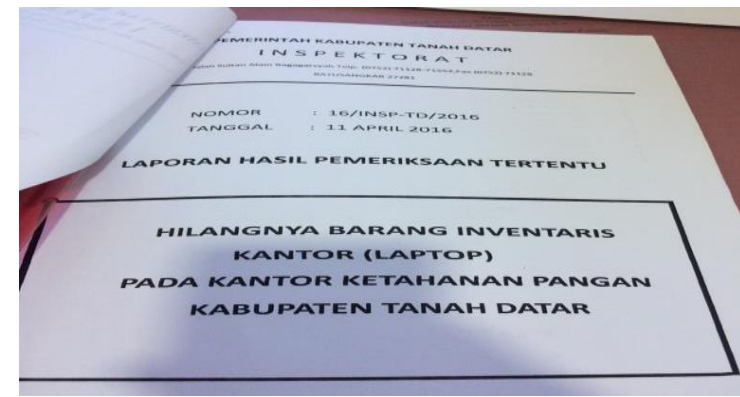

Sumber: (BKPSDM Kabupatn Tanah Datar, 2016 )

(6) Tidak menyalahgunakan informasi intern negara, tugas, status, kekuasaan, dan jabatannya untuk mendapat atau mencari keuntungan atau manfaat bagi diri sendiri atau untuk orang lain. Kekuasaan adalah hak yang dimilki seseorang untuk melakukan sesuatu. Kebanyakan akhir akhir ini banyak Aparatur Sipil Negara yang menggunakan kekuasaannya untuk kepentingan pribadi. Banyak faktor yang menyebabkan hal tersebut terjadi, salah satunya dengan lapangan pkerjaan yang sulit; () Memegang teguh nilai dasar ASN dan selalu menjaga reputasi dan integritas ASN

Memegang nilai teguh merupakan suatu sikap menjunjung nilai nilai ketuhanan, kemanusiaan, keyakinan dan lain lain. Hal tersebut tentu akan menjadi suatu pedoman dan tindakan Aparatur Sipil Negara dalam melaksanakan pekerjaan; (8) Melaksanakan ketentuan peraturan perundang undangan mengenai disiplin Pegawai ASN

Disiplin Aparatur Sipil Negara merupakan suatu tindakan yang berpedoman ataupun tindakan sesuai dengan aturan yang telah ditetapkan. Perlunya disiplin ASN adalah suatu implementasi dalam pelaksanaan Kode Etik ASN.

\section{Gambar 2. Foto Data ASN yang Melakukan Pelanggaran Disiplin}

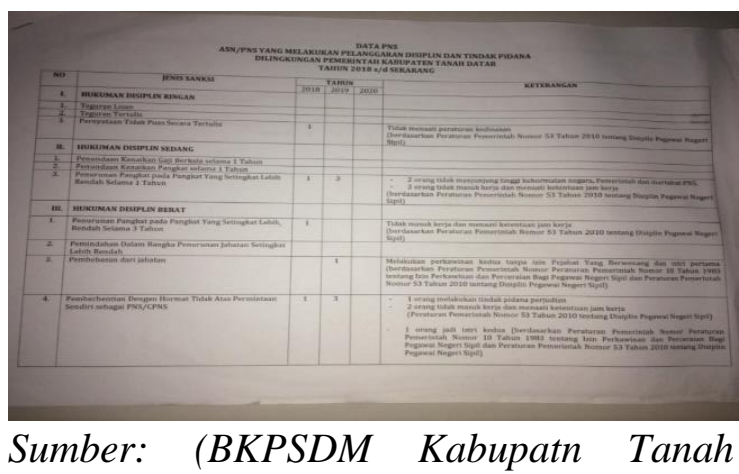

Datar, 2020)

\section{Gambar 3. Foto Data ASN yang Melakukan Pelanggaran Disiplin}

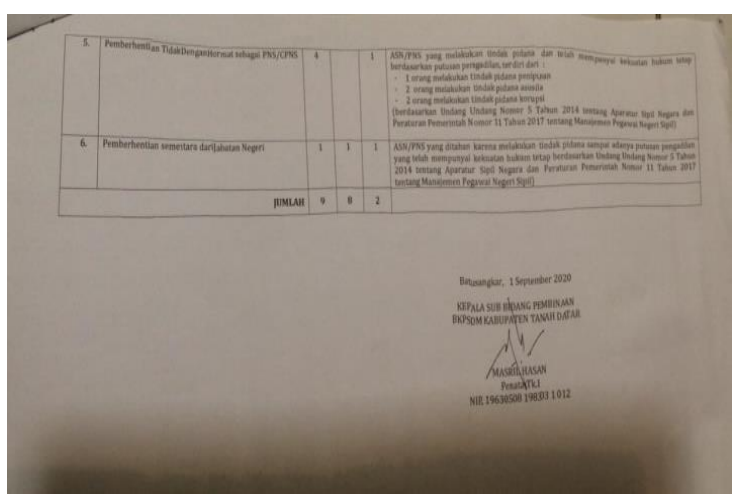

Sumber: (BKPSDM Kabupatn Tanah

Datar, 2020)

Pelaksanaan Kode Etik Aparatur Sipil Negara di Kantor Badan Kepegawaian dan Pengembangan Sumberdaya Manusia Kabupaten Tanah Datar merupakan cara atau acuan bagi pegawai Aparatur Sipil Negara untuk barsikap professional dalam menjalankan tugasnya. Sebelum tau bagaimana Pelaksanaan Kode Etik Aparatur Sipil Negara kita harus tau apa itu Kode Etik. Menurut Peraturan Bupati Tanah Datar Nomor 29 Tahun 2020 pada Pasal 1 menjelaskan Kode Etik adalah pedoman mengenai kewajiban moral Aparatur Sipil Negara yang harus ditunjukkan dalam melaksanakan tugas dan pergaulan hidup sehari-hari. Dalam pengertian diatas dapat dijelaskan bahwa di dalam pelaksanaan Kode Etik Aparatur Sipil Negara terdapat masalah-masalah dan kendala-kendala yang 
harus dipecahkan, mengurangi dan dicegah. Berikut ini kendala-kendala dalam Pelaksanaan Kode Etik Aparatur Sipil Negara di Kantor Badan Kepegawaianan dan Pengembangan Sumberdaya Manusia Kabupaten Tanah Datar.

Sedangkan yang menjadi kendalakendala dalam Pelaksanaan Kode etik Aparatur Sipil Negara di Kantor Badan Kepegawaian dan Pengmbangan Sumber Daya Manusia Kabupaten Tanah Datar yaitu ; (a) Kurangnya sosialisasi yang dilakukan oleh Badan Kepegawaian dan Pengembangan Sumberdaya Manusia (BKPSDM) Kabupaten Tanah Datar dalam melaksanakan Pelaksanaan Kode Etik Aparatur Sipil Negara, sosialisasi hanya di lakukan sekali-sekali, sedangkan sosialisasi merupakan wadah tempat untuk memberikan arahan ataupun gambarannya ; (b) Rendahnya kesadaran Aparatur Sipil Negara merupakan salah satu hambatan dari Pelaksanaan Kode Etik Aparatur Sipil Negara. Para Aparatur Sipil Negara kurang memahami bagaimana harus berprilaku dan bertindak di saat jam kera ; (c) Sumber Daya Manusia yang kurang mempunyai kemampuan dibidang masing-masing dalam menjalankan tugasnya tersebut. Salah satu kunci utama suksesnya Pelaksanaan Kode Etik Aparatur Sipil Negara Ini adalah Sumber Daya Manusia

\section{PENUTUP}

Pelaksanaan Kode Etik Aparatur Sipil Negara Kabupaten Tanah datar, secara umum sudah cukup berjalan sesuai denagn prosedur yang telah ditetapkan. Seperti kejelasan dari melaksanakan tugasnya dengan jujur, bertanggungjawab, dan berintegritas tinggi, melaksanakan tugasnya dengan crmat dan disiplin, melayani dengan sikap hormat, sopan, dan tanpa tekanan, melaksanakan tugasnya sesuai dengan ketentuan peraturan perundang undangan, menggunakan kekayaan dan barang milik negara secara bertanggungjawab, efektif, dan efisien, tidak menyalahgunakan informasi intern negara, tugas, status, keuangan, dan jabatannya untuk mendapat atau mencari keuntungan atau manfaat bagi diri sendiri atau untuk orang lain, memegang teguh nilai dasar ASN dan selalu menjaga reputasi dan integritas ASN, dan melaksanakan ketentuan peraturan perundang undangan mengenai disiplin Pegawai ASN.

Kendala-kendala yang dihadapi dalam pelaksanaan Kode Etik Aparatur Sipil Negara yaitu : (a) komunikasi dalam pelaksanaan Kode Etik Aparatur Sipil Negara belum berjalan dengan efektif karena tidak adanya sosialisasi yang dilakukan secara langsung; (b) rendahnya kesadaran Aparatur Sipil Negara terutama dalam kedisiplinan; (c) kemudian sumberdaya manusia yang dimilki BKPSDM yang tidak memiliki kemampuan di bidang masing-masing dalam menjalankan tugasnya.

Berdasarkan kesimpulan diatas, adapun saran yang akan diberikan penulis terkait Pelaksanaan Kode etik Aparatur Sipil Negara di Kantor Badan Pengembangan Sumberdaya Manusua Kabupaten Tanah Datar yaitu ; (1) Diharapkan kepada pemerintahan agar melanjutkan sosialisasi lagi kepada Aparatur Sipil Negara tentang Kode etik yang telah ditetapkan agar dapat dijalankan. Selain itu pemerintah juga harus lebih tegas terhadap Aparur Sipil Negara yang melanggaran aturan yang telah ditetapkan. Karena sesuai dengan tujuan dari Kode etik yaitu menjaga martabat, kehormatan, citra dan kredibilitas pemerintahan daerah melalui penciptaan tata kerja yang berintegritas, professional dan akuntabilitas serta menciptakan keharmonisan sesame pegawai, dalam rangka mencapai dan mewujudkan visi dan misi pemerintahan daerah; (2) Kepada Aparatur Sipil Negara lebih meningkatkan rasa kesadarannya terhadap peraturan yang telah dibuat, dan dapat memberikan informasi yang jelas kepada masyarakat sehingga masyarakat dapat terlayani sesuai dengan prosedur yang telag ditetapkan. 
Ranti Hanafiah, Karjuni Dt. Maanil Pelaksanaan Kode Etik Aparatur Sipil Negara di Kantor BKPSDM Kabupaten Tanah Datar

\section{DAFTAR KEPUSTAKAAN}

Harbani. 2010. Implementasi Kebijakan Publik. Bandung: Alfabeta.

Indiahono Dwiyanto. 2009. Kebijakan Publik Berbasis Dynamic Policy Analisys. Yogyakarta : Gava Media.

Kusmanadji. 2004. Kode Etik . Jakarta : Gramedia.

Mulyadi, Deddy. 2016. Studi Kebijakan Publik dan Pelayanan Publik. Bandung : Alfabeta.

Solichin. 2014. Implementasi Kebijakan Publik. Yogyakarta : Gava Media.
Nawawi, Juanda dkk. 2019. Kode Etik Aparatur Sipil Negara. Jurnal Ilmu Sosial dan Ilmu Politik. Vol.5, No. 1.

Peraturan Bupati Tanah Datar Nomor 29 Tahun 2020 Tentang"Kode etik dan Kode Perilaku ASN di lingkungan Pemerintahan Kabupaten Tanah Datar".

Peraturan Menteri Dalam Negeri Nomor 28 Tahun $200 \quad$ Tentang"Norma Pengawasan dan Kode Etik Pejabat Pengawas Pemerintah".

Undang-Undang Nomor 5 Tahun 2014 Tentang "Aparatur Sipil Negara". 